\title{
Functional properties of sesame (Sesamum indicum Linn) seed protein fractions
}

\author{
Atinuke O. Idowu ${ }^{1,2^{*}}$ (D) Adeola M. Alashi ${ }^{2}$ D, Ifeanyi D. Nwachukwu ${ }^{2,3}$ (D), Tayo N. Fagbemi ${ }^{4}$ (D) and \\ Rotimi E. Aluko $2,5^{*}$ (D)
}

\begin{abstract}
This work evaluated the functional properties of sesame protein fractions in order to determine their potential in food applications. Sesame seed protein fractions were prepared according to their solubility: water-soluble (albumin), saltsoluble (globulin), alkaline-soluble (glutelin) and ethanol-soluble (prolamin). Globulin was the most abundant fraction, consisting of $91 \%$ protein, followed by glutelin, albumin and prolamin in decreasing order. Non-reducing sodium dodecyl sulfate-polyacrylamide gel electrophoresis (SDS-PAGE) showed polypeptides of sizes $\geq 20 \mathrm{kDa}$ for albumin while glutelin and globulin had similar polypeptide sizes at 19, 85 and $100 \mathrm{kDa}$. Prolamin had polypeptide sizes 20, 40 and $100 \mathrm{kDa}$. The albumin and globulin fractions had higher intrinsic fluorescence intensity (FI) values than the glutelin. Albumin had a higher solubility (ranging from 80 to 100\%) over a wide pH range when compared with the other fractions. Water holding capacity (g/g) reduced from 2.76 (glutelin) to 1.35 (prolamin) followed by 0.42 (globulin) and 0.08 (albumin). Oil holding capacity (g/g) reduced from: 4.13 (glutelin) to 2.57 (globulin) and 1.56, 1.50 for albumin and prolamin respectively. Gelling ability was stronger for prolamin and glutelin than albumin and globulin, while higher emulsion $(p<0.05)$ quality was obtained for prolamin and albumin than for glutelin and globulin.
\end{abstract}

Keywords: Sesame seed, Protein fractions, Functional properties, Foaming capacity, SDS-PAGE

\section{Introduction}

Sesame (Sesamum indicum Linn) is an oilseed legume with high protein content and considerable amounts of essential amino acids. Sesame seeds are very nutritious because they contain about $50 \%$ oil (Kanu et al. 2007) and about (30-60\%) protein (Demirhan and Özbek 2013). It is categorised as an underutilized oilseed with respect to protein extraction and food formulation. Sesame, which is fairly available all year, is an annual crop of the Lamiales order and Pedaliaceae family (Ghosh et al. 2005; Rajeswari et al. 2010). It is known to

\footnotetext{
* Correspondence: aoidowu@mtu.edu.ng; Rotimi.Aluko@umanitoba.ca 'Department of Food Science and Technology, College of Basic and Applied Sciences, Mountain Top University, Km12, Lagos-Ibadan Expressway, Makogi-Oba, Ogun State, Nigeria

2Department of Food and Human Nutritional Sciences, University of Manitoba, 190 Dysart Road, Winnipeg, MB R3T 2N2, Canada Full list of author information is available at the end of the article
}

grow in subtropical and tropical regions, and is well adapted to withstand dry conditions. The sesame seed plant grows on relatively poor soil and in climate unsuitable for other crops. Nearly $70 \%$ of the world's sesame seed production is from Asia with India, China and Myanmar ranking as the world's largest producers of the crop (Namiki 1995). In the African continent which produces $26 \%$ of the world's sesame seed, Sierra Leone, Sudan, Nigeria and Uganda are recognized as the largest producers (Namiki 1995).

In Nigeria, the black (NCRI-97-28) and white (NCRI98-60) sesame seed cultivars are mainly grown. The black cultivar is mainly cultivated in some parts of Katsina state, Kano (Dawanau), and Jigawa (near Hadejia) states, while the white cultivar is mainly grown in Benue (Oturkpo), Nassarawa (Doma), Jigawa (Malammadori) and Taraba states (Makinde and Akinoso 2013). In Nigeria, sesame

(c) The Author(s). 2021 Open Access This article is licensed under a Creative Commons Attribution 4.0 International License, which permits use, sharing, adaptation, distribution and reproduction in any medium or format, as long as you give appropriate credit to the original author(s) and the source, provide a link to the Creative Commons licence, and indicate if changes were made. The images or other third party material in this article are included in the article's Creative Commons licence, unless indicated otherwise in a credit line to the material. If material is not included in the article's Creative Commons licence and your intended use is not permitted by statutory regulation or exceeds the permitted use, you will need to obtain permission directly from the copyright holder. To view a copy of this licence, visit http://creativecommons.org/licenses/by/4.0/. 
seed is underutilised because its use is restricted to the crop-producing regions. The crop is usually exported with minimal processing like cleaning and drying. Locally, oil is usually pressed out from the seed and the residue obtained from it is used with its leaves to prepare a traditional soup called Miyartaushe, in addition to being used as an ingredient in the preparation of other foods. Though its constituents are widely used in food preparation, its utilisation is limited in food applications. This could be as a result of limited information on the structural and functional properties of sesame protein isolate fractions.

Protein fractions are important components of sesame seed and they can be extracted based on their solubility in various media. Functional properties of proteins affect their behaviour in food systems. Therefore, understanding these properties is essential to their application and potential use in food systems.

Reports of earlier workers on functional properties of plant protein fractions include; functional and antioxidant properties of sesame seed flour (Lawal et al. 2019), Buchholzia coriacea seed flour and protein concentrate (Ijarotimi et al. 2018), sesame meal and sesame protein isolate from Indian cultivar (Sharma et al. 2016), bambara vicilin protein fractions (Arise et al. 2017), albumin and globulin fractions from common buckwheat seeds (Tang and Wang 2010), albumin, globulin and protein isolate from soapnut seeds (Yin et al. 2011), as well as albumin, globulin, glutelin and prolamin fractions from Australian canola meals (Tan et al. 2011).

However, information is sparse on the functional properties of sesame seed protein fractions. Therefore, the aim of this study was to evaluate and compare the physicochemical and functional properties (SDS-PAGE, intrinsic fluorescence, surface hydrophobicity, protein solubility, foam capacity, water absorption and oil absorption capacity, least gelation concentration and emulsion capacity) of sesame protein fractions as extracted using different media: water (albumin), salt solution (globulin), alkali solution (glutelin) and the ethanol solution (prolamin) proteins.

\section{Materials and method Materials}

Sesame seeds (NCRI-98-60) cultivars were purchased from a retail market in Kawo, Kaduna state, Nigeria. Reagents and chemicals were obtained from either Fisher Scientific (Oakville, ON, Canada), or Sigma Chemicals (St. Louis, MO, USA). Sesame seeds were milled into flour with a Smartgrind ${ }^{\circ}$ coffee grinder (CBG 100SC model, Black \& Decker, Baltimore, Maryland, USA), followed by defatting using $\mathrm{n}$-hexane for $8 \mathrm{~h}$. The wet defatted flour was air-dried in a fume hood and then stored at $4{ }^{\circ} \mathrm{C}$.

\section{Protein extraction}

Sesame seed protein fractions were prepared using the classical procedure of Osborne as reported by (Tan et al. 2011) with some modifications. Defatted sesame flour $(10 \% \mathrm{w} / \mathrm{v})$ was extracted using ultrapure (Milli-Q ${ }^{\circ}$, Millipore Corporation) water for $2 \mathrm{~h}$ with constant stirring. The extract was centrifuged at $6500 \mathrm{x} g$ for 30 min and the resultant supernatant was filtered using cheesecloth (Fisher Scientific, 6665-8). The residue was re-extracted with ultrapure water as described and the filtrates were pooled together and freeze-dried as the albumin fraction. The residue was sequentially resuspended in $2 \% \mathrm{NaCl}, 0.1 \mathrm{M} \mathrm{NaOH}$ and $70 \%$ ethanol to obtain globulin, glutelin and prolamin fractions following corresponding centrifugation and filtration steps. To remove the salt and ethanol in the globulin and prolamin samples respectively, both fractions were separately dialyzed against 20 volumes of deionized water at $4{ }^{\circ} \mathrm{C}$ using 6-8 kDa molecular weight cut-off (MWCO) Spectra/Por1 cellulose membranes (Spectrum Labs, Rancho Dominguez, CA, USA). The dialysis was carried out over 3 days with four daily changes of water. For glutelin, the fraction was adjusted to $\mathrm{pH} 4.0$ with $1 \mathrm{M} \mathrm{HCl}$ and centrifuged at $6500 \mathrm{x} \mathrm{g}$ for $30 \mathrm{~min}$ to obtain a precipitate that was then re-suspended in five volumes of deionised water and adjusted to $\mathrm{pH} 7.0$ with $1 \mathrm{M} \mathrm{NaOH}$. All the extracted protein fractions were freeze-dried and stored at $-20^{\circ} \mathrm{C}$ until needed for further tests. The isoelectric precipitation method, described by Malomo et al. (2014) was used to prepare protein isolate, which is required for the calculation of protein yield of the sesame protein fractions. Defatted sesame flour $(10 \%, \mathrm{w} / \mathrm{v})$ was suspended in deionized water, the $\mathrm{pH}$ of the suspension was adjusted to 9.5 using $1 \mathrm{M} \mathrm{NaOH}$ and stirred continuously for $1 \mathrm{~h}$ at $50^{\circ} \mathrm{C}$. The solution was then centrifuged at $4000 \mathrm{x} \mathrm{g}$ for $10 \mathrm{~min}$ at $4{ }^{\circ} \mathrm{C}$. The supernatant obtained was adjusted to $\mathrm{pH} 4.9$ using $1 \mathrm{M} \mathrm{HCl}$ and stirred for $20 \mathrm{~min}$. The precipitate obtained after centrifugation was washed twice with distilled water to remove salt, re-dispersed in deionized water and $\mathrm{pH}$ adjusted to 7.0 prior to freeze-drying to obtain the sesame protein isolate. The protein yield was calculated in relation to the protein isolate, in order to determine the proportion of each of the protein fractions. The gross weight of the individual freeze-dried protein fractions was obtained, as well as the weight of the protein isolate. The yield obtained was calculated as the ratio of the percentage gross weight of the individual freeze-dried protein fraction to the weight of sesame protein isolate (SPI) (Sathe and Venkatachalam 2007).

\section{Sodium dodecyl sulfate-polyacrylamide gel electrophoresis (SDS-PAGE)}

Reducing and non-reducing Sodium dodecyl sulfatepolyacrylamide gel electrophoresis (SDS-PAGE) was 
carried out on the freeze dried protein fractions (albumin, globulin, glutelin and prolamin) (Aluko and McIntosh (2004)) with minor modifications. The samples were suspended $(10 \mathrm{mg} / \mathrm{mL})$ in Tris/HCl buffer, $\mathrm{pH} 8.0$ containing SDS (10\% concentration) with $10 \% \beta$-mercaptoethanol for the reducing lane and that, containing only SDS for the non-reducing lane. This was succeeded by heating $\left(95^{\circ} \mathrm{C}\right.$, $10 \mathrm{~min}$ ), cooling and centrifugation. This was followed by loading $1 \mu \mathrm{L}$ of supernatant onto $8-25 \%$ gradient gels, in order to carry out the electrophoresis with Phast system Separation and Development units (GE Healthcare, Montréal, PQ, Canada). The molecular weight marker of standard proteins $(10-200 \mathrm{kDa})$, and the gels were stained with Coomassie blue was used to analyse the approximate molecular weights and proportions of the protein in each of the scanned gel using the Image Quant TL 1D software program (GE Healthcare, Montréal, PQ, Canada).

\section{Intrinsic fluorescence}

Fluorescence intensity (FI) spectra of the protein samples were obtained with the use of a JASCO FP-6300 spectrofluorimeter (Jasco, Tokyo, Japan) at $25^{\circ} \mathrm{C}$ using a 1-cm path length cuvette as previously reported ( $\mathrm{Li}$ and Aluko 2006). Stock solutions of the protein fractions (20 $\mathrm{mg} / \mathrm{mL}$, protein content basis) were prepared in $0.1 \mathrm{M}$ sodium phosphate buffer of various $\mathrm{pH}$ viz. $\mathrm{pH} 3.0,5.0$, 7.0 and 9.0. The mixture was shaken for $1 \mathrm{~h}$ at $25^{\circ} \mathrm{C}$, followed by centrifugation. The supernatant of each protein fraction was diluted to $0.025 \mathrm{mg} / \mathrm{mL}$ and the samples were excited at $280 \mathrm{~nm}$ while emission was recorded from 290 to $500 \mathrm{~nm}$. Fluorescence emission spectra of the samples were obtained by deducting the emission spectrum of respective buffer blanks from the emission spectrum of samples. The FI was expressed in arbitrary units while $\mathrm{F}_{\max }$ is the maximum FI and $K_{\max }$ is the wavelength at $\mathrm{F}_{\max }$.

\section{Surface hydrophobicity $\left(\mathrm{H}_{\mathrm{o}}\right)$}

Surface hydrophobicity, $\mathrm{H}_{\mathrm{o}}$ was performed using a hydrophobic fluorescence probe, 1-anilino-8-nephtalene sulphonate (ANS) according to a method described by Hayakawa and Nakai (1985) with slight modifications. The stock solution for each sample was serially diluted to a fixed concentration range of $0.005-0.025 \% \mathrm{w} / \mathrm{v}$ (based on protein content) using $0.1 \mathrm{M}$ sodium phosphate buffer ( $\mathrm{pH} 7.0)$. A $10 \mu \mathrm{L}$ aliquot of ANS $(8.0 \mathrm{mM}$ in $0.1 \mathrm{M}$ sodium phosphate buffer, $\mathrm{pH} 7.0$ ) was added to $200 \mu \mathrm{L}$ of each diluted sample. A fluorescence spectrophotometer (JASCO FP-6300, Tokyo Japan) was used to obtain the fluorescence intensity (FI) of each mixture at wavelengths of 390 and $470 \mathrm{~nm}$ used as excitation and emission respectively. Surface (aromatic) hydrophobicity $\left(\mathrm{H}_{\mathrm{o}}\right)$ was obtained from a plot of the initial slope of the
FI versus sample concentration (calculated by linear regression analysis).

\section{Protein solubility}

The samples' protein solubility was determined using the method of Malomo et al. (2014). The use phosphate buffer is to stabilize and maintain the $\mathrm{pH}$ of the solution. This is because the $\mathrm{pH}$ meter sometimes does not stabilize the acidity or alkalinity of the solution.

The two phosphate salts (monosodium phosphate and disodium phosphate) were used to ensure enough availability of ions to resist changes in the $\mathrm{pH}$ of the solution especially for proteins. The phosphate buffers were prepared in accordance with the required $\mathrm{pH}$ values using the two salts, following the Arrhenius equations. Sodium Phosphate buffer $(0.1 \mathrm{M})$ was used to prepare buffer at various $\mathrm{pH}: 3,5,7,9$ by measuring the standard quantity required for each $\mathrm{pH}$ value and dissolving it in distilled water. Samples $(10 \mathrm{mg} / \mathrm{mL}$ protein weight basis) were mixed with $0.1 \mathrm{M}$ sodium phosphate buffer solutions with the pH range 3.0-9.0 and each of the resulting mixtures was vortexed for $2 \mathrm{~min}$ and centrifuged at 10,000 $\mathrm{x}$ $\mathrm{g}$ for $20 \mathrm{~min}$. This was followed by determination of the protein content of the supernatant using the modified Lowry method (Markwell et al. 1978). Total protein content was determined by dissolving the isolated protein fractions in $0.1 \mathrm{M} \mathrm{NaOH}$ solution. Protein solubility (PS) was expressed as a percentage ratio of supernatant protein content to the total protein content.

\section{Foam capacity (FC)}

FC was determined according to the method described by (Ijarotimi et al. 2018). Buffer solution was prepared at $\mathrm{pH}, 3.0,5.0,7.0$ and 9.0 using $0.1 \mathrm{M}$ phosphate solution. The samples were weighed into $50 \mathrm{~mL}$ graduated centrifuge tubes as 20, 40 and $60 \mathrm{mg} / \mathrm{mL}$ (protein weight basis) and $5 \mathrm{~mL}$ of $0.1 \mathrm{M}$ phosphate buffer, $\mathrm{pH} 3.0,5.0$, 7.0, and 9.0 were added to each tube. The mixtures were homogenized at 20,000 rpm for 1 min with a $20 \mathrm{~mm}$ foaming shaft on the polytron PT 3100 homogenizer (Kinematica AG, Lucerne, Switzerland).

Foam capacity $\mathrm{FC}=\frac{\text { volume after homogenization-volume before homogenization }}{\text { volume before homogenization }} \times 100$

The obtained foam was left to stand for about $30 \mathrm{~min}$ at room temperature. The foam stability was calculated by measuring the final foam volume after 30 min storage at room temperature and expressed as a percentage of the original foam volume.

\section{Water and oil holding capacity}

The water holding capacity (WHC) and oil holding capacity $(\mathrm{OHC})$ were carried out using the method of 
Adebiyi and Aluko (2011) with minor modifications. Protein sample $(1 \mathrm{~g})$ was mixed in $10 \mathrm{~mL}$ distilled water (or pure canola oil) in a $15 \mathrm{~mL}$ pre-weighed centrifuge tube. The dispersions were vortexed for $1 \mathrm{~min}$, allowed to stand for $30 \mathrm{~min}$ and then centrifuged at $7000 \mathrm{x}$ g for $25 \mathrm{~min}$ at room temperature. The supernatant was decanted, and the excess water (or oil) was drained while the sediment was weighed to determine the amount of water or oil retained per gram of sample.

\section{Least gelation concentration (LGC)}

LGC was determined using the method of Adebiyi and Aluko (2011) by mixing the samples thoroughly with water at $2-20 \%(\mathrm{w} / \mathrm{v})$ solids concentration in test tubes. Three sets of samples were obtained for each protein fraction, one was as dispersed with water (the $\mathrm{pH}$ of the water used was slightly acidic around, $\mathrm{pH}$ 6.5), while the other two sets of samples were adjusted to $\mathrm{pH} 7$ and 9 respectively. The resulting mixtures were swirled in a vortex, placed in a water bath at $95^{\circ} \mathrm{C}$ for $1 \mathrm{~h}$, cooled rapidly under tap water and cooled at $4{ }^{\circ} \mathrm{C}$ for $14 \mathrm{~h}$. The LGC was taken as the sample concentration at which the gel did not slip when the tube was inverted.

\section{Emulsion formation and measurement}

Emulsion formation and measurement was achieved using the method of Ijarotimi et al. (2018) with some modifications. Samples (10, 25, or $50 \mathrm{mg} / \mathrm{mL}$ protein weight basis) were weighed into $50 \mathrm{~mL}$ graduated centrifuge and $5 \mathrm{~mL}$ of $0.1 \mathrm{M}$ sodium phosphate buffer $\mathrm{pH} 3.0$, 5.0, 7.0,or 9.0 were added, followed by the addition of 1 $\mathrm{mL}$ of pure canola oil. The oil/water mixture was thoroughly mixed together at 20,000 rpm for $1 \mathrm{~min}$, using the $20 \mathrm{~mm}$ non-foaming shaft on a Polytron PT 3100 homogenizer. The oil droplet size $(\mathrm{d} 3,2)$ of the emulsions was measured using a Mastersizer 2000 (Malvern Instruments Ltd., Malvern, U.K.) with deionized water serving as dispersant. Under constant shearing, the emulsion sample was drawn from the tubes and released into wet sample dispersion unit (Hydro 2000S) containing about $100 \mathrm{~mL}$ of water which was attached to the instrument. The reading was not taken until the required level of obscuration was reached and the instrument was set to measure each emulsion in triplicate automatically.

The obtained emulsion was left for about $30 \mathrm{~min}$ at room temperature without agitation. The emulsion stability was measured as the increases in mean particle volume diameter $\left(\mathrm{d}_{4,3}\right)$ after $30 \mathrm{~min}$.

\section{Statistical analysis}

All analyses were performed in triplicates and the data obtained were subjected to analysis of variance and Duncan's multiple range tests to determine significant differences $(p<0.05)$ between mean values using Statistical Package for Social sciences (SPSS) software, version 20.

\section{Results and discussion SDS-PAGE}

It has been reported that variations in polypeptide profiles of proteins have impact on functional properties, especially on the emulsion and gelation capacity (Aluko and McIntosh 2001; Mundi and Aluko 2012; Tan et al. 2011). SDS-PAGE was used to separate protein fractions according to their electrophoretic mobility as a function of polypeptide molecular weight (Fig. 1). Under nonreducing condition, three distinct bands were observed for the albumin profile (lane 1) at 20, 70 and $80 \mathrm{kDa}$ respectively with the $20 \mathrm{kDa}$ in the highest proportion. Other bands were at 25, 40 and $50 \mathrm{kDa}$. The nonreduced glutelin (lane 2) and globulin (lane 3) had most of their bands at similar polypeptide positions $(19,40$, $42,50,55,60,70,85$ and $100 \mathrm{kDa}$ ), with the highest proportion at the $19 \mathrm{kDa}$ position. Prolamin (lane 4) had its bands at 10, 20, 40, 48, 52, 75, 83 and $87 \mathrm{kDa}$ polypeptide positions.

Under the reducing condition for albumin (lane 2), the bands observed $(10,25,40$ and $47 \mathrm{kDa})$ suggest a high level of disulphide bonds in the protein. Some higher molecular weight proteins $(70$ and $80 \mathrm{kDa})$ were replaced by lower molecular weight proteins $(10,25,40$ and 47 $\mathrm{kDa}$ ). Under reduced condition, glutelin bands were observed at 10,12, 15, 20, 27, 30, 35, 40, 65, 80 and 85 $\mathrm{kDa}$. Some of the higher molecular weight bands observed for glutelin under non-reduced condition were still intact in the reduced condition while some others were replaced by lower molecular weight polypeptides. For globulin (lane 4), the bands observed under reduced condition are 10, 15, 20, 22, 30, 32, 35, 40, 65, 80 and $85 \mathrm{kDa}$; which implies that most of the polypeptide positions were retained when mercaptoethanol was added. Since some of the higher molecular weights were replaced by smaller polypeptides, it is evident that this protein fraction contains inter-molecular disulphide bonds. Under reduced condition, prolamin showed bands at $8,11,17,23,25,30,38,40,45$ and $60 \mathrm{kDa}$ polypeptide positions. Similar disappearance of high molecular weight proteins in the presence of mercaptoethanol has been reported for hemp seed (Malomo et al. 2014) and African yam bean seed (Ajibola et al. 2016).

\section{Yield of protein fractions}

The relative amounts of sesame protein fractions, obtained by fractionating into albumin, globulin, glutelin and prolamin in the different solvent systems: water, salt solution, alkali solution and ethanol solution respectively are presented in Table 1 . The yield obtained was calculated as the ratio of the percentage 


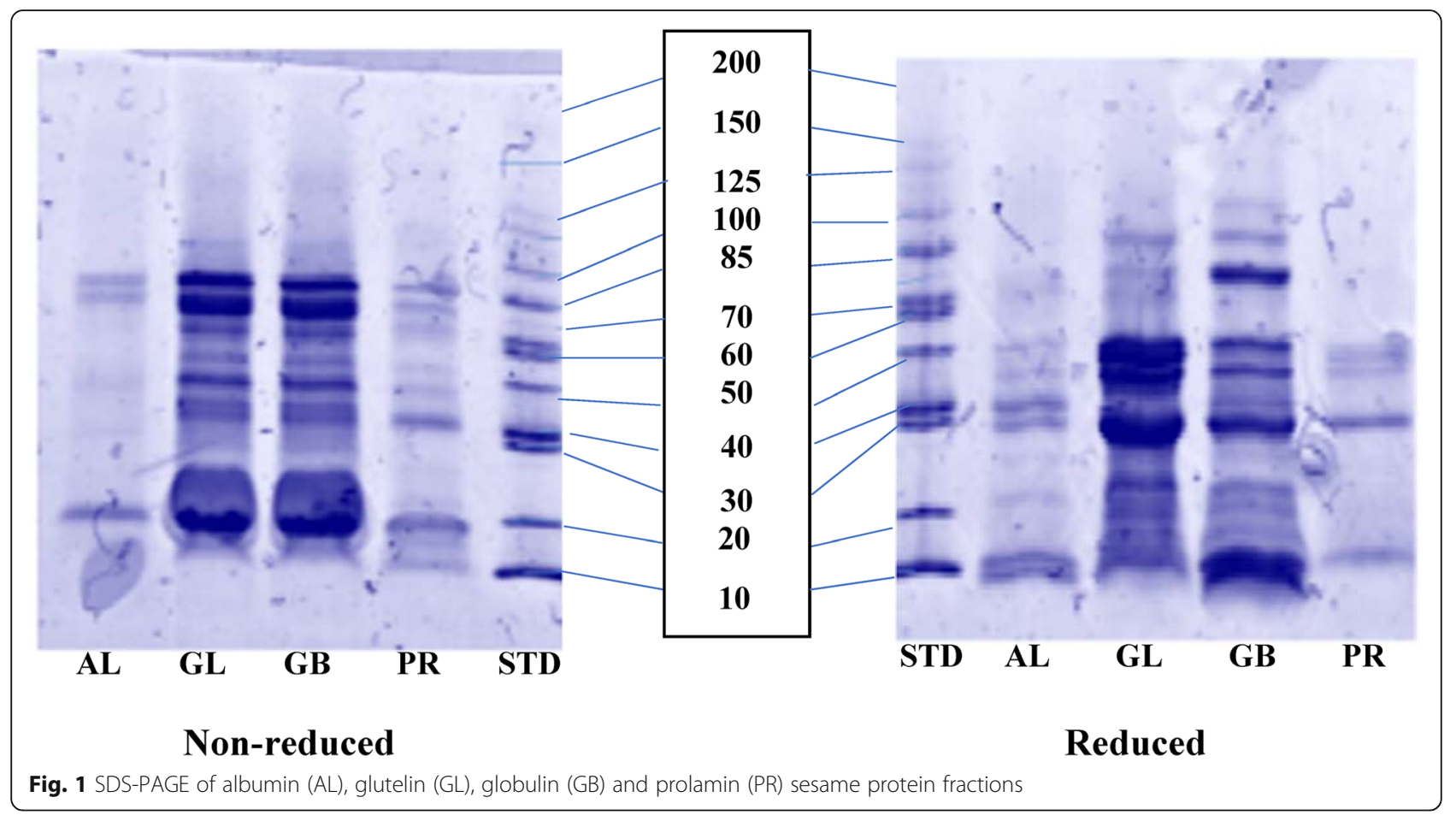

gross weight of the individual freeze-dried protein fraction to the weight of sesame protein isolate (SPI) (Sathe and Venkatachalam 2007). The gross yield of albumin, globulin, prolamin and glutelin were 17.34, $3.79,2.64$ and $23.17 \%$, respectively. For the protein yield, the glutelin $(47.42 \%)$ was the most predominant protein fraction, followed by albumin (22.84\%), globulin (10.52\%) and prolamin (1.29\%). The high protein yield of glutelin may be because the sesame protein isolate (used for calculation) was precipitated at $\mathrm{pH} 4.9$ (isoelectric point). High amount of albumin suggests the presence of protein with hydrophilic properties.

The results obtained for the protein content of sesame protein fractions indicate that the quantity obtained for globulin is significantly $(p<0.05)$ higher than other fractions. Okubo et al. (1979) also reported globulin as the major protein fraction in sesame proteins. However, Adebiyi and Aluko (2011) reported albumin as the highest protein content of commercial yellow field pea protein isolate. Protein content obtained for globulin (91.43\%) and albumin (43.40\%) is comparable to the values reported for crude protein content of African yam bean globulin (91.68\%) and albumin (59.51\%) by Ajibola et al. (2016). The differences in protein contents of the sesame protein fractions may be due to differences in the extraction materials and different methods of protein precipitation. The significantly $(p<0.05)$ least protein value obtained for prolamin (ethanol extract) may be as a result of its insolubility in the solvent used for the protein determination and the inclusion of nonprotein materials that may have been extracted during fractionation by the ethanol solution.

\section{Intrinsic fluorescence (FI)}

Fluorescence intensity indicates how much light is emitted (i.e., the extent of emission). It is used to determine position and microenvironment (hydrophobicity or hydrophilic) of aromatic amino acids within the protein tertiary structure. The microenvironment change of aromatic amino acid residues of bovine serum albumin (BSA) was studied and reported to vary at different $\mathrm{pH}$ (Guang et al. (2000).

Table 1 Gross, protein yield and protein content of sesame protein fractions isolated from defatted sesame meal

\begin{tabular}{lllllll}
\hline & Protein content (\%) & Total carbohydrate content (\%) & Protein yield (\%) & Gross yield (\%) & WHC (g/g) & OHC (g/g) \\
\hline Albumin & $43.40 \pm 1.23^{c}$ & $23.42 \pm 1.22^{\mathrm{a}}$ & $22.84 \pm 0.72^{\mathrm{b}}$ & $17.34 \pm 0.55^{\mathrm{a}}$ & $0.08 \pm 0.00^{\mathrm{d}}$ & $1.56 \pm 0.05^{\mathrm{c}}$ \\
Globulin & $91.43 \pm 1.45^{\mathrm{a}}$ & $2.192 \pm 3.30^{\mathrm{c}}$ & $10.52 \pm 1.10^{\mathrm{c}}$ & $3.79 \pm 0.40^{\mathrm{c}}$ & $0.42 \pm 0.02^{\mathrm{c}}$ & $2.57 \pm 0.06^{\mathrm{b}}$ \\
Glutelin & $67.44 \pm 1.65^{\mathrm{b}}$ & $1.11 \pm 1.31^{\mathrm{d}}$ & $47.42 \pm 0.30^{\mathrm{a}}$ & $23.17 \pm 0.14^{\mathrm{b}}$ & $2.76 \pm 0.06^{\mathrm{a}}$ & $4.13 \pm 0.05^{\mathrm{a}}$ \\
Prolamin & $16.88 \pm 0.88^{\mathrm{d}}$ & $5.02 \pm 0.04^{\mathrm{b}}$ & $1.29 \pm 1.41^{\mathrm{d}}$ & $2.64 \pm 0.17^{\mathrm{c}}$ & $1.35 \pm 0.01^{\mathrm{b}}$ & $1.50 \pm 0.04^{\mathrm{c}}$ \\
\hline
\end{tabular}


The fluorescence properties of tyrosine and tryptophan can be used as a measure of changes in the protein structure (Schmid 1989). The tertiary structure of protein indicates the position of amino acid residues within the three-dimensional configuration. The least fluorescence intensity (FI) value obtained for glutelin (Fig. 2) indicates that its protein molecules are highly denatured. This denaturation resulted in the opening up of the tyrosine and tryptophan residues to the environment (hydrophilic), which contributed to reduced fluorescence. An increase was observed in the FI of the glutelin fraction as the environment changed from acidic to alkaline environment. The $\mathrm{pH}$ increase had positive effect on FI which may be due to increased net charge (resulting from protonation of carboxyl and amine groups), which resulted in increased interactions between the hydrophobic amino acid residues and reduced interaction with the hydrophilic environment to attenuate fluorescence quenching, hence high FI. On the contrary, albumin had the highest fluorescence at all measured $\mathrm{pH}$ values $(\mathrm{pH} 3,5,7$ and 9), followed by globulin only at $\mathrm{pH} 5,7$, \& 9. The results suggest less denatured protein molecules for the albumin and globulin, thereby reducing the exposure of its tyrosine and tryptophan residues to the environment (which is hydrophilic). Generally, albumin and globulin had higher FI values than the glutelin. Ajibola et al. (2016) made a similar report on African yam bean albumin and globulin having a higher FI than its protein isolate.

\section{Surface hydrophobicity $\left(\mathrm{H}_{\mathrm{o}}\right)$}

Surface hydrophobicity shows the number of hydrophobic amino acids on the surface of proteins when they are folded and helps to discover changes in the distribution of hydrophobic groups at the surface of protein when they are folded. These changes are caused by protein denaturation during processing which consequently leads to changes in the molecular

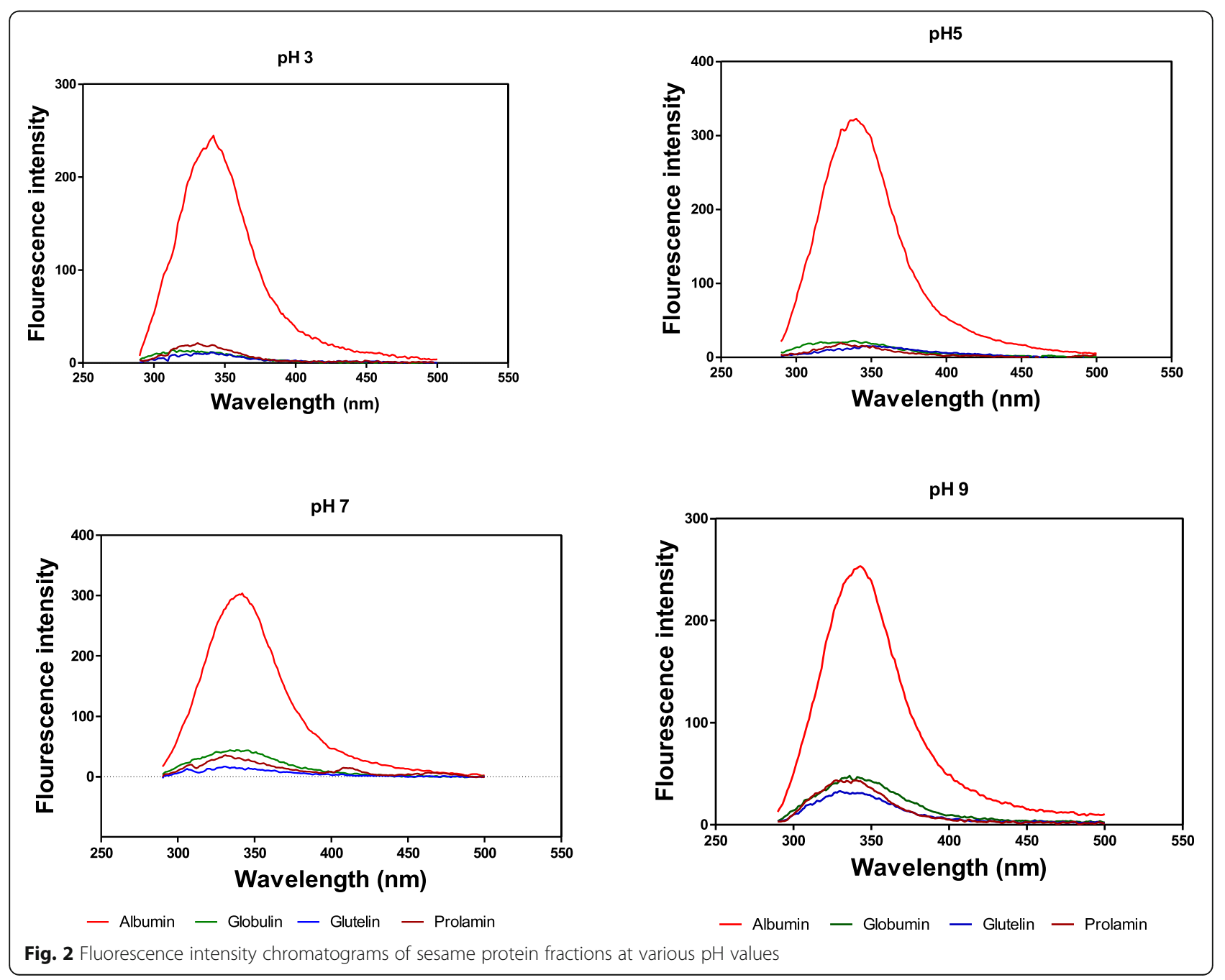


structure of proteins (Mune et al. 2016). Surface hydrophobicity of globulin was significantly $(p<0.05)$ higher than those of other fractions (Fig. 3). The surface hydrophobicity of glutelin and prolamin are not significantly $(p>0.05)$ different. The $\mathrm{H}_{\mathrm{o}}$ of albumin is significantly $(p<0.05)$ the least $\mathrm{H}_{\mathrm{o}}$ among the protein fractions. The low surface hydrophobicity values observed in the albumin fractions might be due to its hydrophilic nature (decreased exposure of hydrophobic groups), which pushes the hydrophobic groups into the protein interior (Uruakpa and Arntfield 2005). The high value of surface hydrophobicity observed for globulin might be attributed to the availability of more non-polar amino acids for interaction with ANS. The interactions between polar amino acid residues might lead to electrostatic repulsions that unfold the proteins and thus exposing more hydrophobic amino acids to the surface, hence increased surface hydrophobicity (Jiang et al. 2015). This result suggests that more hydrophobic amino acids would be available on the surface of the globulin fraction in the present study at $\mathrm{pH}$ 7.0. As the hydrophobic amino acid level increases, there would be greater adsorption at the oil-water interface and this is required for emulsion formation of the protein isolates ( $\mathrm{Li}$ et al. 2019).

\section{Protein solubility of sesame protein fractions}

Protein solubility at various $\mathrm{pH}$ values gives an indication of the extent of protein denaturation due to heat or chemicals and how well the isolate will perform when used in food formulations (Horax et al. 2004). In many protein-based formulations, such as emulsions, foams and gels, good protein solubility is usually required. It affects texture, colour, and sensory properties of food products (Meng and Ma 2002; Shand et al. 2007). The albumin fraction has a high solubility over the $\mathrm{pH}$ range used, with values ranging between 80 and 125\% (Fig. 4). Similar results were reported for the albumin fraction of African yam bean seed (Ajibola et al. 2016), pea seed (Adebiyi and Aluko 2011) and sunflower (Pérez et al. 2005). Potential usefulness of albumin includes formation of acidic drinks, desserts, non-acidic beverages and other liquid beverages whose properties may facilitate consumers' acceptance (Meng and Ma 2002; Rangel et al. 2003).

The solubility of the globulin was significantly higher at the alkaline $\mathrm{pH}$ than acidic $\mathrm{pH}$, which may be due to increased net protein charge as $\mathrm{pH}$ was increased. This is similar to the result reported for other legume proteins (Chavan et al. 2001; Rangel et al. 2003).

Solubility profile of glutelin showed minimum solubility around $\mathrm{pH} 4.5-7.0$ which is the region of highest protein aggregation. This facilitates electrostatic repulsion between the protein molecules, which enhances protein insolubility (Malomo and Aluko 2015; Mundi and Aluko 2012). Low protein solubility of prolamin may be attributed to the fact that prolamins are insoluble in aqueous solution. This is similar to the report of Adebiyi and Aluko (2011) on insolubility of commercial yellow field pea seed prolamin in aqueous solution. It is important to note that the albumin protein fraction exhibited higher solubility at $\mathrm{pH} \geq 7.0$, thus indicating that it could be easily incorporated into products that have neutral or basic $\mathrm{pH}$ values.

\section{Foaming capacity (FC) and foam stability (FS)}

Foaming capacity refers to the ability of protein to form flexible and cohesive film at the water -air interface due to its solubility in water. (Elsohaimy et al. 2015; Ijarotimi et al. 2018). It is important in the manufacture of foods such as ice cream and cakes, which require foam formation. Foaming capacity was greatly influenced by $\mathrm{pH}$ (Fig. 5).

Generally, pH was observed to affect the foaming capacity of all sesame protein fractions and the least foaming capacity was observed around pH5.0 (except for albumin), which is the point of least protein solubility. Protein solubility is a pre-requisite for good foaming properties. The $\mathrm{pH}$-dependent foaming characteristics were also observed in albumin, globulin and protein isolate of Ginkgo biloba seeds (Deng et al. 2011), sesame protein concentrates (Cano-Medina et al. 2011) and in albumin and globulin fractions of African locust bean (Lawal et al. 2005). Junting et al. (2012); Elsohaimy et al. (2015) reported $\mathrm{pH}$-dependent solubility (which is closely related to foaming capacity) for sesame and quinoa seeds respectively. Film thickness, mechanical strength and some other properties of protein film are required for the foam to be stable. Foam stability indicates the ability of the foam to retain its volume and shape over a period of time. It's desirable in some beverages and food products such as beer, and baked products. The foaming stability of the sesame protein fractions are shown in Fig. 6. Foaming stability values vary with $\mathrm{pH}$, protein concentration and it differs from one sesame protein fraction to the other. For example, albumin and globulin had less stability than glutelin and prolamin at $\mathrm{pH} 3$ and 9. This may be due to weak interfacial membrane, which could not prevent the coalescence of the particle. Adebiyi and Aluko (2011) reported a similar trend for albumin. But a contrary report was made by Zakidou and Paraskevopoulou (2021) that aqueous sesame seed extract exhibits increased foaming stability values with higher $\mathrm{pH}$ values, which suggests the formation of strong interfacial membrane (increased charge on the membrane) that prevented coalescence of the foam particles. 1 . 


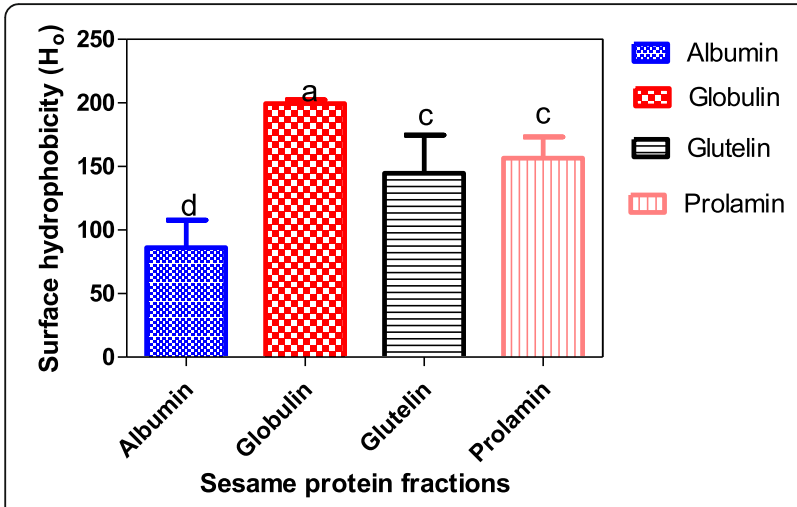

Fig. 3 Surface hydrophobicity of sesame protein fractions

\section{Water and oil holding capacity}

Water holding capacity (WHC) refers to the ability protein particles in food to adsorb and retain water against gravity (Chavan et al. 2001). It is referred to as the amount of water a sample can absorb per unit weight. This water includes bound water, hydrodynamic water, capillary water and physically entrapped water. The property is based on direct interaction of protein molecules with water and other solutes (Khalid et al. 2003). WHC values for sesame protein fractions (Table 1) show that albumin is highly soluble in water as a large quantity of the sample was dissolved in water. A similar observation was made by Ajibola et al. (2016) for albumin fraction of African yam bean. A low water holding capacity was also reported for albumin fractions of Ginkgo biloba seeds by Deng et al. (2011). A previous report showed that proteins with high solubility had low WHC (Cheng-Mei et al. 2018; Sharma et al. 2016), as it is applicable to the albumin in this study. On the other hand, prolamin (with the least solubility) was observed to have the highest WHC among the fractions followed by glutelin and then globulin.
Oil holding capacity $(\mathrm{OHC})$ refers to the amount of oil a sample can absorb per unit of weight. It also entails interactions of protein surface area, size, charge and hydrophobicity. A similar $\mathrm{OHC}$ was obtained for albumin $(1.56 \mathrm{~g} / \mathrm{g})$ and prolamin $(1.50 \mathrm{~g} / \mathrm{g})$ fractions (Table 1 ). The value obtained for albumin in this work is lower than the value reported for albumin fraction of biloba seed (9.3 mL/g; assuming $1 \mathrm{~mL}=1 \mathrm{~g}$ ) (Deng et al. 2011). $\mathrm{OHC}$ values $2.57 \mathrm{~g} / \mathrm{g}$ and $4.13 \mathrm{~g} / \mathrm{g}$ obtained for globulin and glutelin, respectively are comparable to the values reported for African yam bean seed globulin $(4.75 \mathrm{~g} / \mathrm{g}$ ) and protein concentrate (Ajibola et al. 2016).

\section{Least gelation concentration (LGC)}

Gelation concentration is one of the functional properties that is useful in food applications. It is the ability of proteins to congeal as gel, thereby, holding water, flavour, sugars and food ingredients together (Kinsella 1979). LGC is the lowest protein concentration at which the gel remained in the inverted tube without falling off (Moure et al. 2006). Hence, the lower the LGC value, the better gelling ability. The gelation capacity in Fig. 7 indicates higher gel formation capacity for prolamin and glutelin respectively, when compared with globulin and albumin. The LGC value obtained in this study for glutelin is lower than the $10 \%$ value documented for commercial yellow field pea glutelin (Adebiyi and Aluko 2011). Also, comparable with the results obtained for globulin in this work, Sathe and Salunkhe (1981) reported that the salt soluble fraction (globulin), did not form a strong gel up to $20 \%(\mathrm{w} / \mathrm{v})$ concentration range. However, the low gelling ability result obtained for albumin in this work is contrary to the value of $8 \%$ obtained for African yam bean albumin (Ajibola et al. 2016). The lower gelling ability of the sesame seed albumin may be due to smaller number of hydrophobic clusters as earlier

\section{Protein solubility curve}

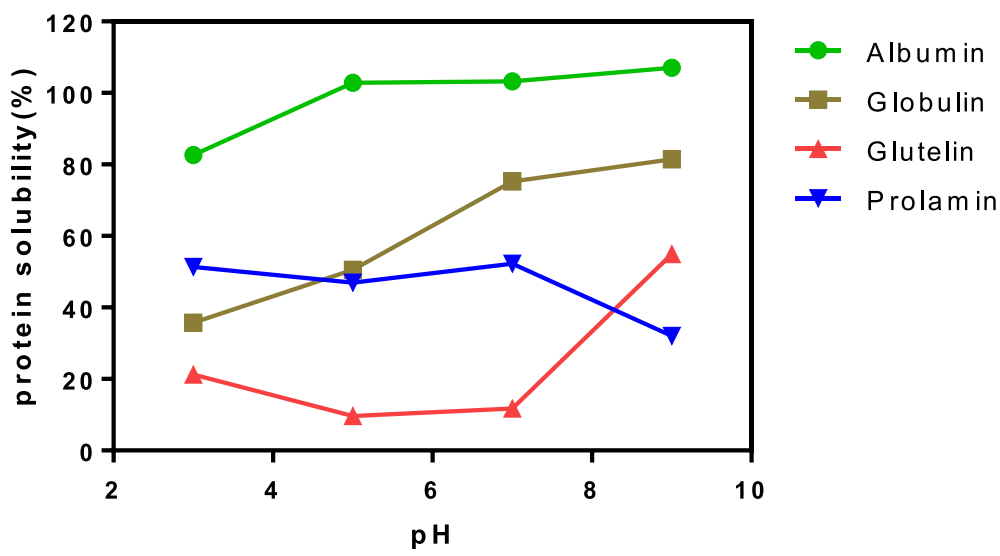

Fig. 4 Protein solubility curve of sesame protein fractions 

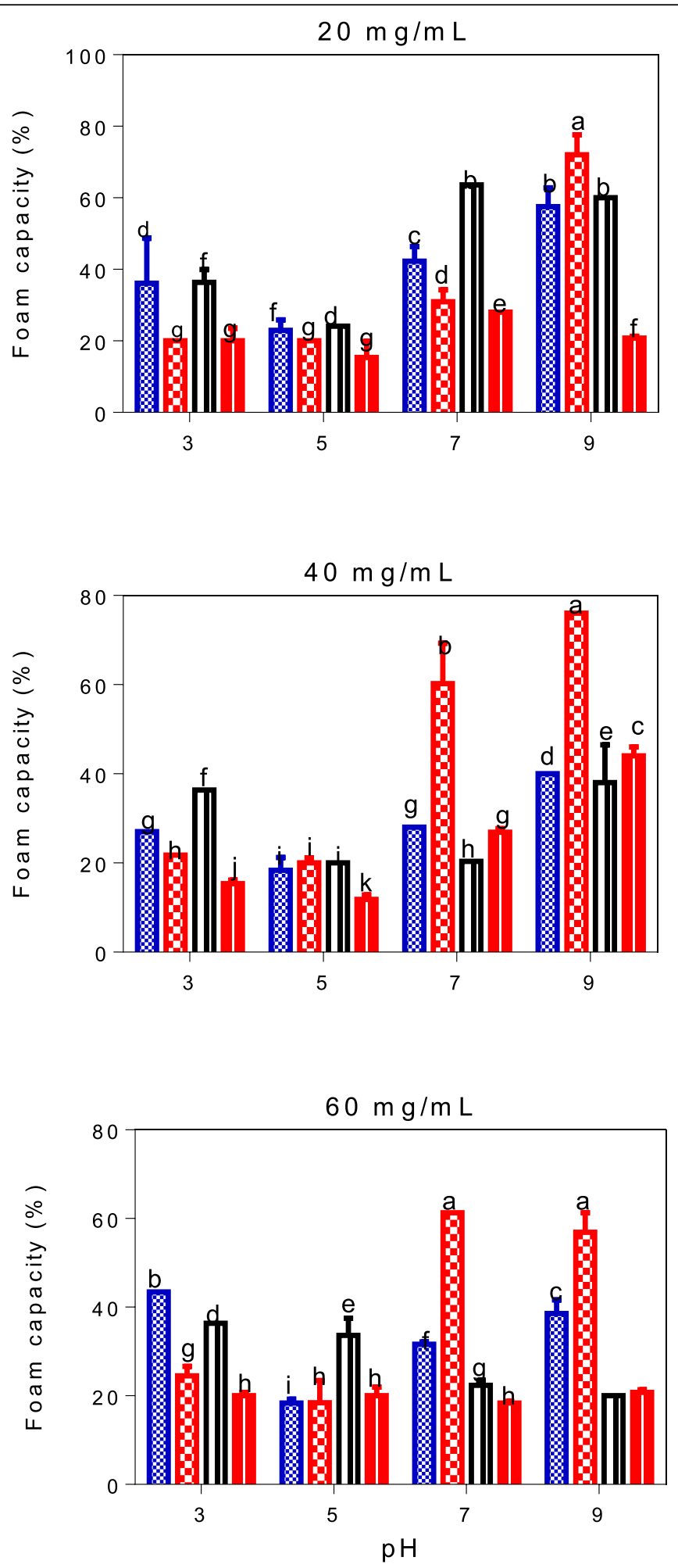

880 Albumin

E Globulin

II Glutelin

III prolamin

Fig. 5 Effect of $\mathrm{pH}$ and protein concentration on foaming capacity of sesame protein fractions 

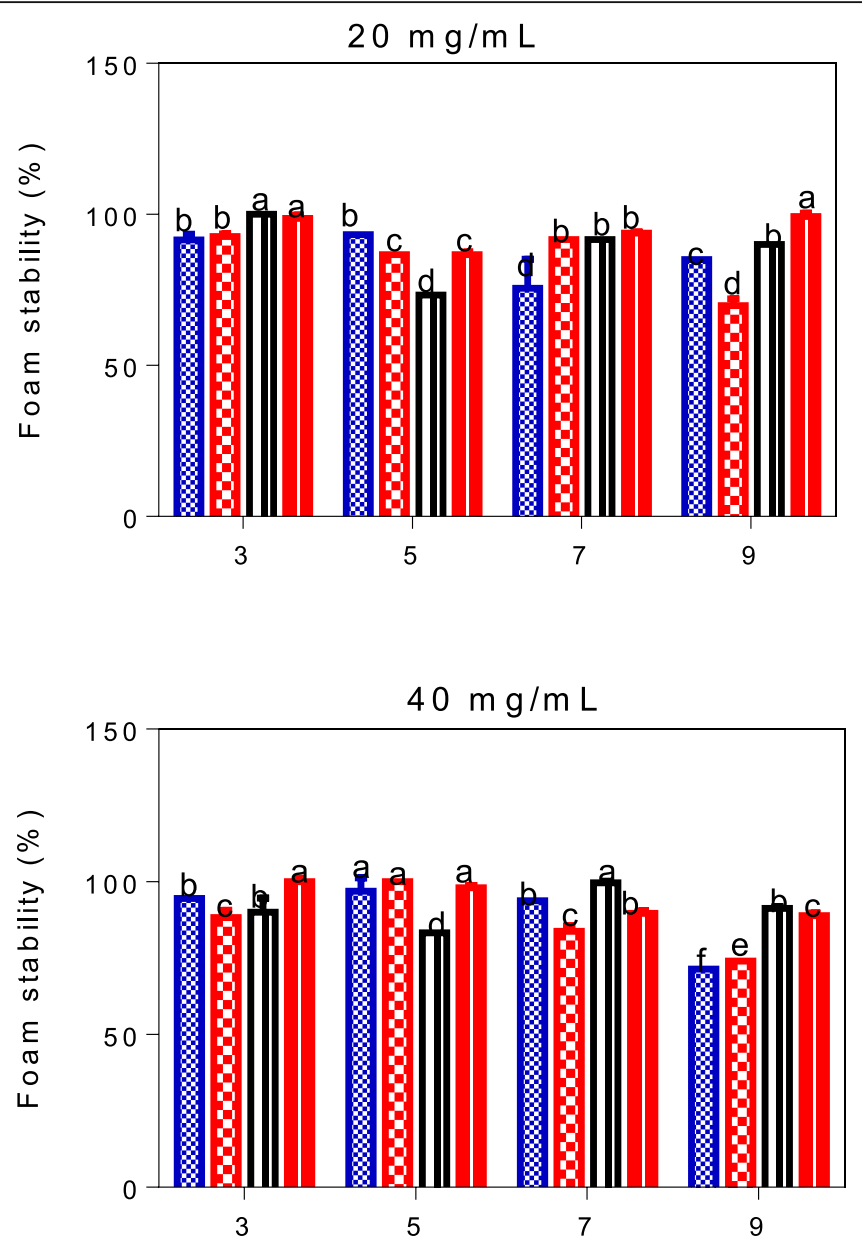

$60 \mathrm{~m} \mathrm{~g} / \mathrm{m} \mathrm{L}$

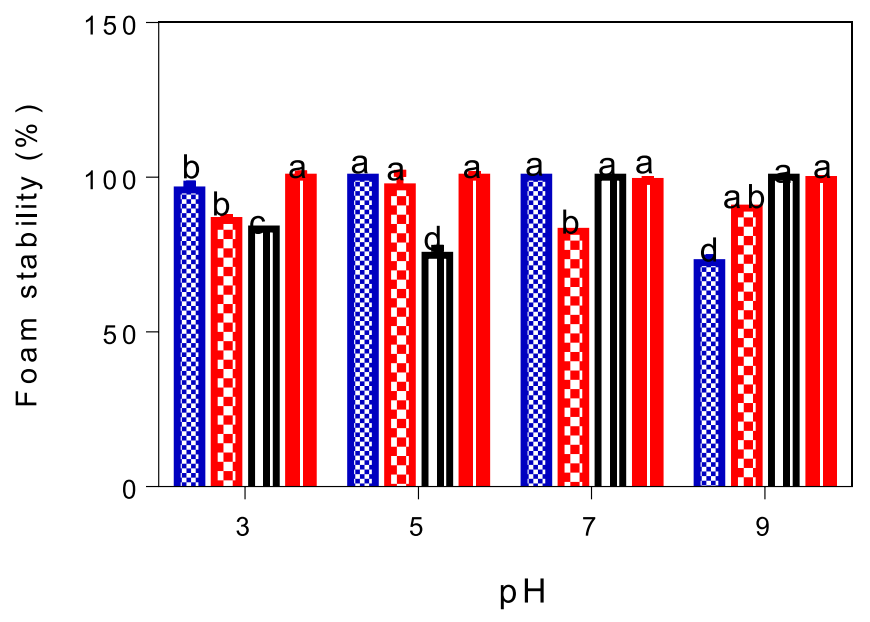

Albumin Globulin Glutelin

Prolam in

Fig. 6 Effect of pH and protein concentration on foaming stability of sesame protein fractions 


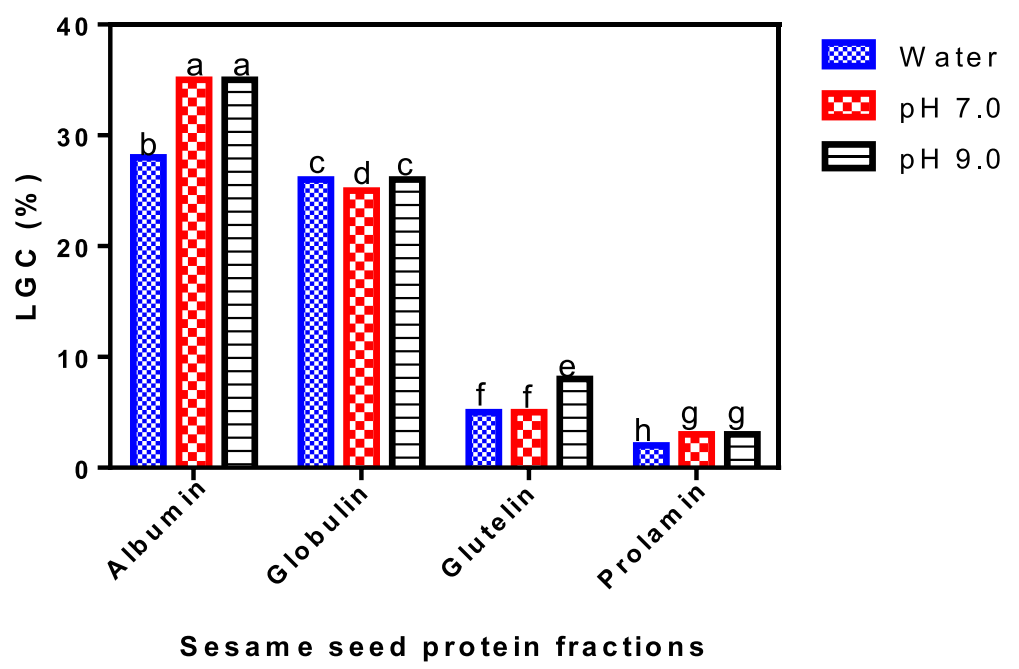

Fig. 7 Gelation concentration of sesame protein fractions

reported for buckwheat albumin (Tang and Wang 2010), which could reduce its protein-protein attractions. Also, the protein-water interactions in the albumin fractions (which is facilitated by the presence of abundant levels of hydrophilic sugar), may have contributed to the lower gelation capacity, since higher gelation capacity is enhanced by protein-protein interaction.

\section{Emulsion capacity (EC) and emulsion stability (ES)}

Most food products exist in water and oil phases, therefore evaluation of their emulsion-forming ability is essential to indicate the usefulness of these food products as functional food ingredients in the food industry (Liu et al. 2013). Emulsion quality is determined by oil droplet size $\left(d_{3,2}\right)$. An inverse relationship exists between the emulsion quality and oil droplet size, whereby a smaller oil droplet size indicates good emulsion forming capacity (Famuwagun et al. 2020).

Oil droplet size reduction was observed in the samples as sample concentration increased from $10 \mathrm{mg} / \mathrm{mL}$ to $50 \mathrm{mg} / \mathrm{mL}$, which indicates increased emulsion forming ability (Fig. 8). This may be as a result of increases in protein content/concentration which led to availability of more protein at the oil-water interface, leading to formation of stronger and a higher number of interfacial membranes. A similar trend was reported for protein isolates prepared from edible vegetable leaves by Famuwagun et al. (2020).

At most of the $\mathrm{pH}$ values, lower oil droplet sizes (higher emulsion quality) were obtained for prolamin and albumin fractions. The better emulsifying quality obtained in prolamin fraction may be as a result of its hydrophobic characteristic, which enhanced its interactions with the lipid phase. A similar report was documented for the prolamin value of yellow field pea (Adebiyi and Aluko 2011). This could be largely due to the presence of large amounts of non-protein materials such as polysaccharides which could improve emulsification. Although prolamin exhibited a good emulsion property, its low yield (Table 1) will be a disadvantage, when considered for use as a functional food ingredient.

Higher emulsion quality (smaller oil droplet sizes) obtained for albumin than those of globulin and glutelin is possibly due to the presence of more folded structure in the globulin proteins which minimises the encapsulation ability of the oil droplets (poor interfacial property), when compared to a more open or flexible protein structures in albumin. This implies that albumin is a better emulsifier than globulin. Also, change in $\mathrm{pH}$ affected the emulsion-forming ability. For instance, smaller oil droplets $(p<0.05)$ were formed for glutelin and prolamin at pH 7.0 and 9.0, which suggests optimal proteinprotein repulsion that facilitated protein solubility and encapsulation ability. This is similar to the report of Adebiyi and Aluko (2011), who reported that isolates and glutelin fractions from pea proteins had better emulsification (reduced oil droplet size) at neutral and alkaline conditions. Ijarotimi et al. (2018) also reported similar results for seed flour and protein concentrate of wonderful cola (Buchholzia coriacea) seeds. Yin et al. (2010) reported that kidney bean phaseolin-rich exhibited a poor emulsifying activity at $\mathrm{pH} 3.0$ but good at pH7.0 and 9.0. The emulsion property of albumin did not show substantial changes at different $\mathrm{pH}$ values, which is also consistent with the fact that the albumin protein had similar solubility over a wide $\mathrm{pH}$ range. The emulsion stability result (Fig. 9), suggests a significant difference $(p<0.05)$ for the fractions at all $\mathrm{pH}$ values. 

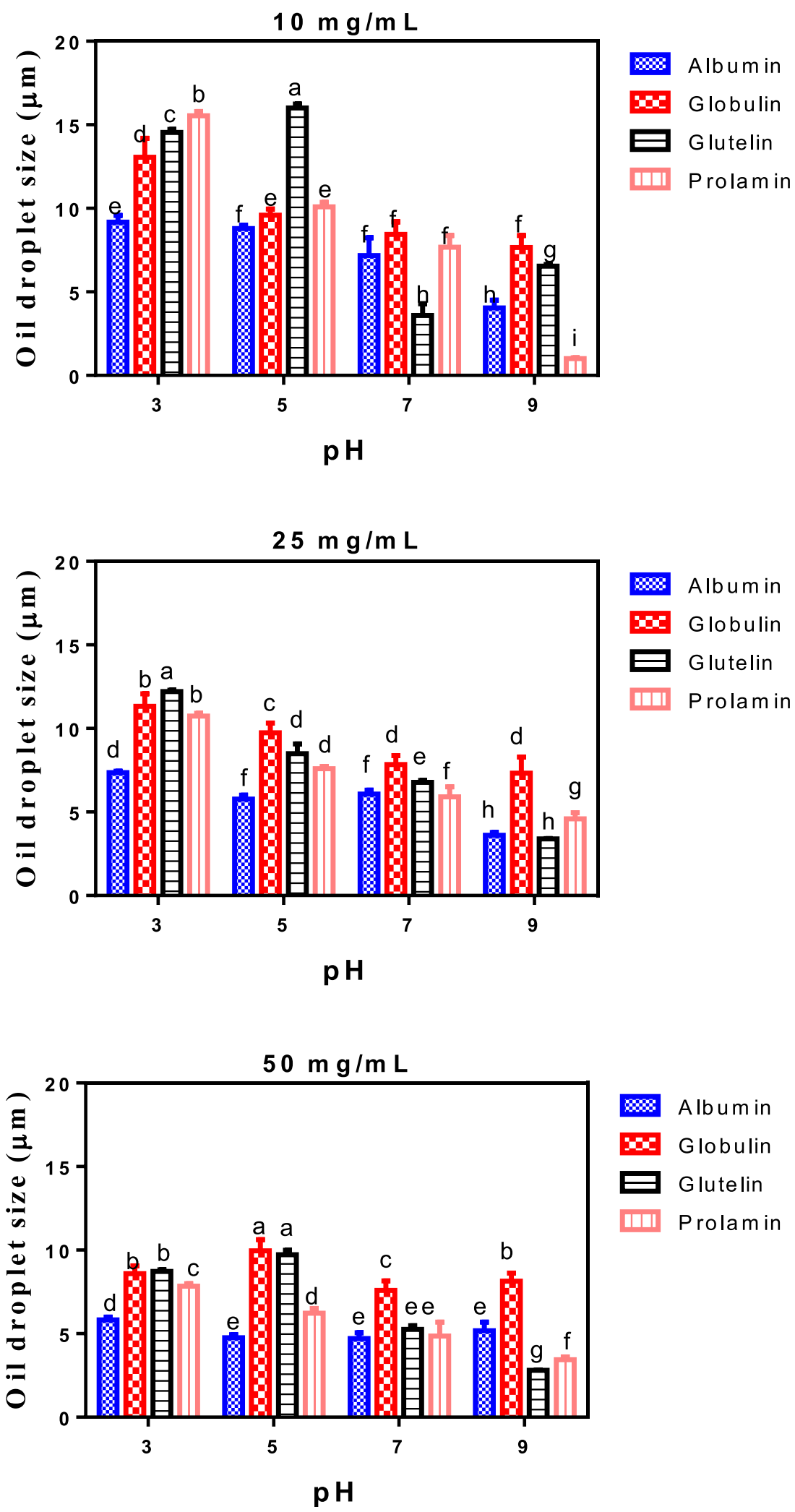

88 Albumin

III Globulin

Elutelin

[III Prolam in

Fig. 8 Effect of pH and sample protein concentration on emulsion capacity of sesame protein fractions 

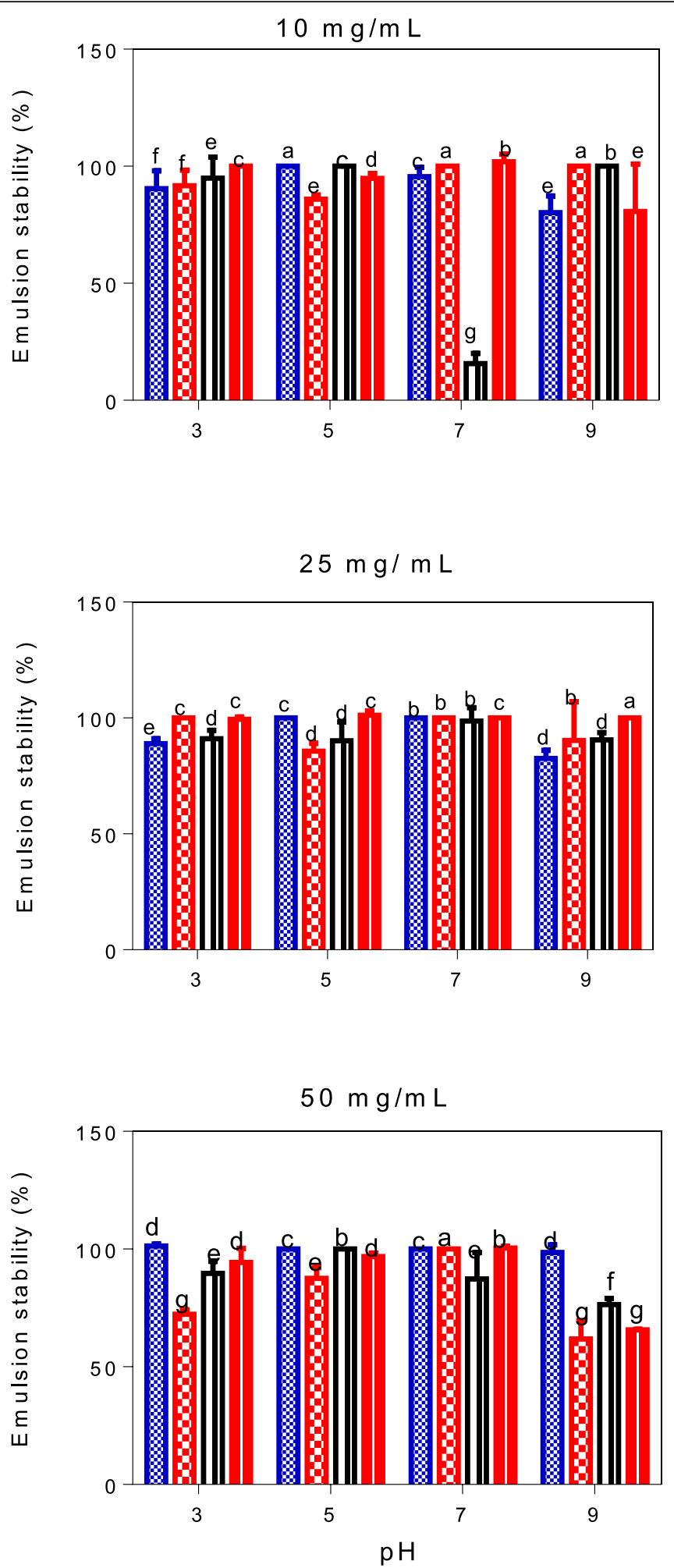

828 Albumin Globulin 10 Glutelin

Fig. 9 Effect of $\mathrm{pH}$ and sample protein concentration on emulsion stability of protein fractions 
The emulsion was observed to be more stable from $\mathrm{pH} 3$ to 5 , which is attributed to the reduction in net molecular charges thus facilitating increased protein-protein interactions, thereby enhancing formation of strong interfacial membranes. This is similar to the report of Mundi and Aluko (2012) on albumin and globulin protein fractions of kidney bean.

At $50 \mathrm{mg} / \mathrm{mL}$ (increased protein concentration), the emulsion stability of the globulin and prolamin fractions were observed to decrease considerably at $\mathrm{pH} 9$, when compared to the emulsion stability at lower protein concentrations $(10 \mathrm{mg} / \mathrm{mL}$ and $25 \mathrm{mg} / \mathrm{mL})$ and at $\mathrm{pH} 3,7$ and 5 . This is as a result protein congestion at the 50 $\mathrm{mg} / \mathrm{mL}$ concentration, which could have resulted in a rise in protein charge and consistent viscosity of the phase (Nwachukwu and Aluko 2018). The rise in the protein charge would translate to elevated proteinprotein repulsions while the heightened viscosity would translate to a decreased rate of polypeptide movement within the oil-water interface, resulting in weaker interfacial membrane, which increases the chances of rupture and coalescence of the oil droplet (Nwachukwu and Aluko 2018). On the contrary, Malomo and Aluko (2015), reported no decrease in emulsion stability for hemp seed globulin at increased protein concentration, $50 \mathrm{mg} / \mathrm{mL}$.

\section{Conclusion}

The findings from this study have shown that samples produced from sesame protein fractions have potential for use as a basic functional ingredient in the food industry. The globulin fraction constitutes the highest proportion, followed by glutelin, then albumin while prolamin was the least. Foaming capacity, protein solubility and some other functional properties are $\mathrm{pH}$-dependent.

The lower LGC and smaller oil droplet sizes (higher emulsion quality) of glutelin and prolamin suggest that their polypeptides have less folded (compact) structures than that of globulin.

\section{Abbreviations \\ SDS-PAGE: Sodium dodecyl sulfate-polyacrylamide gel electrophoresis; SPI: Sesame protein isolate; FI: TFluorescence intensity; ANS: 1-anilino-8- nephtalene sulphonate; PS: Protein solubility; FC: Foam capacity; WFC: Water holding capacity; OHC: Oil holding capacity; BSA: Bovine serum albumin; Fl: Fluorescence intensity; FC: Foaming capacity; FS: Foam stability; LGC: Least gelation concentration; EC: Emulsion capacity; ES: Emulsion stability \\ Acknowledgements \\ We acknowledge support of the Natural Sciences and Engineering Research Council of Canada (NSERC), funding reference number RGPIN 2018-06019. Cette recherche a été financée par le Conseil de recherches en sciences nat- urelles et en génie du Canada (CRSNG), numéro de référence RGPIN 2018- 06019. Our acknowledgement also goes to the Mountain Top University for funding the living expenses of the researcher in the course of this research.}

\section{Authors' contributions}

AO was involved in the conception of this study, sample preparation laboratory analysis of samples, data analysis, data interpretation, data presentation, and drafting of the manuscript. MA was involved in some of the laboratory analysis and some of the data interpretation. ID participated in some of the data analysis and some of the data presentation. TN was involved in the conception of this study and in the review of the manuscript. RE was involved in the design of this study, supervision of the laboratory analysis and in the review of the manuscript. All authors read and approved the final manuscript.

\section{Funding}

Natural Sciences and Engineering Research Council of Canada (NSERC), funding reference number RGPIN 2018-06019. Cette recherche a été financée par le Conseil de recherches en sciences naturelles et en génie du Canada (CRSNG), numéro de référence RGPIN 2018-06019.

\section{Availability of data and materials}

The data and the materials are included in the manuscript and available for public use on request.

Ethics approval and consent to participate

Not applicable.

\section{Consent for publication}

Not applicable.

\section{Competing interests}

The authors declare they have no competing interests.

\section{Author details}

'Department of Food Science and Technology, College of Basic and Applied Sciences, Mountain Top University, Km12, Lagos-lbadan Expressway, Makogi-Oba, Ogun State, Nigeria. ${ }^{2}$ Department of Food and Human Nutritional Sciences, University of Manitoba, 190 Dysart Road, Winnipeg, MB R3T 2N2, Canada. ${ }^{3}$ Center for Nutrition \& Healthy Lifestyles, School of Public Health, Loma Linda University, 24951 North Circle Drive, Loma Linda, CA 92350, USA. ${ }^{4}$ Department of Food Science and Technology, Federal University of Technology, Akure, P.M.B. 704, Akure, Nigeria. ${ }^{5}$ Richardson Centre for Functional Foods and Nutraceuticals, University of Manitoba, 196 Innovation Drive, Winnipeg, MB R3T 2N2, Canada.

Received: 10 September 2020 Accepted: 14 December 2020 Published online: 28 January 2021

\section{References}

Adebiyi, A. P., \& Aluko, R. E. (2011). Functional properties of protein fractions obtained from commercial yellow field pea (Pisum sativum L.) seed protein isolate. Food Chemistry, 128(4), 902-908. https://doi.org/10.1016/j.foodchem. 2011.03.116.

Ajibola, C. F., Malomo, S. A., Fagbemi, T. N., \& Aluko, R. E. (2016). Polypeptide composition and functional properties of African yam bean seed (Sphenostylis stenocarpa) albumin, globulin and protein concentrate. Food Hydrocolloids, 56, 189-200.

Aluko, R. E., \& Mclntosh, T. (2001). Polypeptide profile and functional properties of defatted meals and protein isolates of canola seeds. Journal of the Science of Food and Agriculture, 81(4), 391-396.

Aluko, R. E., \& McIntosh, T. (2004). Electrophoretic and functional properties of mustard seed meals and protein concentrates. JAOCS, Journal of the American Oil Chemists' Society, 81(7), 679-683.

Arise, A. K., Nwachukwu, I. D., Aluko, R. E., \& Amonsou, E. O. (2017). Structure, composition and functional properties of storage proteins extracted from bambara groundnut (Vigna subterranea) landraces. International Journal of Food Science \& Technology, 52(5), 1211-1220.

Cano-Medina, A., Jiménez-Islas, H., Dendooven, L., Herrera, R. P., González-Alatorre, G., \& Escamilla-Silva, E. M. (2011). Emulsifying and foaming capacity and emulsion and foam stability of sesame protein concentrates. Food Research International, 44(3), 684-692.

Chavan, U. D., McKenzie, D. B., \& Shahidi, F. (2001). Functional properties of protein isolates from beach pea (Lathyrus maritimus L.). Food Chemistry, 74(2), 177-187.

Cheng-Mei, L., Peng, Q., Liu, W., Ye-Jun, Z., \& Wang, F. (2018). Molecular and functional properties of protein fractions and isolate from cashew nut (Anacardium occidentale L.). Molecules, 23(2), 393. 
Demirhan, E., \& Özbek, B. (2013). Influence of enzymatic hydrolysis on the functional properties of sesame cake protein. Chemical Engineering Communications, 200(5), 655-666.

Deng, Q., Wang, L., Wei, F., Xie, B., Huang, F., Huang, W., ... Xue, S. (2011). Functional properties of protein isolates, globulin and albumin extracted from Ginkgo biloba seeds. Food Chemistry, $124(4), 1458-1465$

Elsohaimy, S. A., Refaay, T. M., \& Zaytoun, M. A. M. (2015). Physicochemical and functional properties of quinoa protein isolate. Annals of Agricultural Sciences, 60(2), 297-305.

Famuwagun, A. A., Alashi, M. A., Gbadamosi, S. O., Taiwo, K. A., Oyedele, D. J., Abebooye, O. C., \& Aluko, R. E. (2020). Comparative study of the structural and functional properties of protein isolates prepared from edible vegetable leaves. International Journal of Food Properties, 23(1), 955-970. https://doi.org/ 10.1080/10942912.2020.1772285

Ghosh, P., Ghosal, P., Thakur, S., Lerouge, P., Loutelier-Bourhis, C., Driouich, A., \& Ray, B. (2005). Polysaccharides from Sesamum indicum meal: Isolation and structural features. Food Chemistry, 90, 719-726.

Guang, P., Xue, Y., Guang, P., \& Fen, X. (2000). Spectral study of the microenviroment change of aromatic amino-acid residues in BSA induced by pH. PMed, 20(4), 556-559.

Hayakawa, S., \& Nakai, S. (1985). Contribution of hydrophobicity, net charge and sulfhydryl groups to thermal properties of ovalbumin. Canadian Institute of Food Science and Technology Journal, 18(4), 290-295.

Horax, R., Hettiarachchy, N. S., Chen, P., \& Jalaluddin, M. (2004). Functional properties of protein isolate from cowpea (Vigna unguiculata L. Walp.). Journal of Food Science, 69(2), 119-121.

ljarotimi, O. S., Malomo, S. A., Fagbemi, T. N., Osundahunsi, O. F., \& Aluko, R. E. (2018). Structural and functional properties of Buchholzia coriacea seed flour and protein concentrate at different $\mathrm{pH}$ and protein concentrations. Food Hydrocolloids, 74, 275-288

Jiang, L., Wang, Z., Li, Y., Meng, X., Sui, X., Qi, B., \& Zhou, L. (2015). Relationship between surface hydrophobicity and structure of soy protein isolate subjected to different ionic strength. International Journal of Food Properties, 18(5), 1059-1074

Junting, Z., Daliang, L., Fusheng, C., \& Guoji, L. (2012). Functional properties of sesame seed protein prepared by two different methods.(report). Journal of the Chemical Society of Pakistan, 34(5).

Kanu, P. J., Kerui, Z., Ming, Z. H., Haifeng, Q., Kanu, J. B., \& Kexue, Z. (2007). Sesame protein 11: Functional properties of sesame (Sesamum indicum L.) protein isolate as influenced by $\mathrm{pH}$, temperature, time and ratio of flour to water during its production. Asian Journal of Biochemistry, 2, 289-301. https://doi. org/10.3923/ajb.2007.289.301.

Khalid, E. K., Babiker, E. E., \& El Tinay, A. H. (2003). Solubility and functional properties of sesame seed proteins as influenced by $\mathrm{pH}$ and/or salt concentration. Food Chemistry, 82, 361-366. https://doi.org/10.1016/ S03088146(02)00555-1.

Kinsella, J. E. (1979). Functional properties of soy proteins. Journal of the American Oil Chemists' Society, 56(3), 242-258.

Lawal, O. S., Adebowale, K. O., Ogunsanwo, B. M., Sosanwo, O. A., \& Bankole, S. A. (2005). On the fuctional properties of globulin and albumin protein fractions and flours of African locust bean (Parkia biglobossa). Food Chemistry, 92, 681-691.

Lawal, S. O., Idowu, A. O., Malomo, S. A., Badejo, A. A., \& Fagbemi, T. N. (2019). Effect of toasting on the chemical composition, functional and antioxidative properties of full fat and defatted sesame (Sesamum indicum $\mathrm{L}$ ) seed flours. Journal of Culinary Science \& Technology. https://doi.org/10.1080/15428052. 2019.1681333.

Li, H., \& Aluko, R. E. (2006). Bovine colostrum as a bioactive product against human microbial infection and gastro intestinal disorders. Current Topics in Nutraceutical Research, 4(3-4), 227-237.

Li, J., Wang, B., Fan, J., Zhong, X., Huang, G., Yan, L., \& Ren, X. (2019). Foaming, emulsifying properties and surface hydrophobicity of soy proteins isolate as affected by peracetic acid oxidation. International Journal of Food Properties, 22(1), 689-703. https://doi.org/10.1080/ 10942912.2019.1602540.

Liu, F., Chen, Z., Wang, L., \& Wang, R. (2013). Effects of protein solubilisation and precipitation $\mathrm{pH}$ values on the functional properties of defatted wheat germ protein isolates. International Journal of Food Science \& Technology, 48(7), 1490-1497.
Makinde, F. M., \& Akinoso, R. (2013). Nutrient composition and effect of processing treatments on anti nutritional factors of Nigerian sesame (Sesamum indicum Linn) cultivars. International Food Research Journal, 20(5), 2293-2300.

Malomo, S. A., \& Aluko, R. E. (2015). A comparative study of the structural and functional properties of isolated hemp seed (Cannabis sativa L.) albumin and globulin fractions. Food Hydrocolloids, 43, 743-752.

Malomo, S. A., He, R., \& Aluko, R. E. (2014). Structural and functional properties of hemp seed protein products. Journal of Food Science, 79(8), C1512-C1521.

Markwell, M. A. K., Haas, S. M., Bieber, L. L., \& Tolbert, N. E. (1978). A modification of the Lowry procedure to simplify protein determination in membrane and lipoprotein samples. Analytical Biochemistry, 87(1), 206-210.

Meng, G., \& Ma, C. Y. (2002). Characterization of globulin from Phaseolus angularis (red bean). International Journal of Food Science \& Technology, 37(6), 687-695.

Moure, A., Sineiro, J., Dominguez, H., \& Parajo, J. C. (2006). Functionality of oilseed protein products: A review. Food Research International, 39, 945-963.

Mundi, S., \& Aluko, R. E. (2012). Physicochemical and functional properties of kidney bean albumin and globulin protein fractions. Food Research International, 48(1), 299-306.

Mune, M. A., Bassogog, C. B. B., Nyobe, E. C., \& Minka, S. R. R. (2016) Physicochemical and functional properties of Moringa oleifera seed and leaf flour. Cogent Food \& Agriculture, 2(1), 1220352. https://doi.org/10. 1080/23311932.2016.1220352

Namiki, M. (1995). The chemistry and physiological functions of sesame. Food Reviews International, 11(2), 281-329. https://doi.org/10.1080/ 87559129509541043

Nwachukwu, I. D., \& Aluko, R. E. (2018). Physicochemical and emulsification properties of flaxseed (Linum usitatissimum) albumin and globulin fractions. Food Chemistry, 255, 216-225.

Okubo, K., Nishimura, N., \& Shibasaki, K. (1979). Composition of sesame seed protein components and purification of the main globulin. Cereal Chemistry, 100-104.

Pérez, S. G., Vereijken, J. M., Koningsveld, G. A., Gruppen, H., \& Voragen, A. G. J. (2005). Physicochemical properties of $2 S$ albumins and the corresponding protein isolate from sunflower ( Helianthus annuus). Journal of Food Science, 70(1), C98-C103.

Rajeswari, S., Thiruvengadam, V., \& Ramaswamy, N. M. (2010). Production of interspecific hybrids between Sesamum alatum Thonn and Sesamum indicum L. through ovule culture and screening for phyllody disease resistance. South African Journal of Botany, $76(2), 252-258$

Rangel, A., Domont, G. B., Pedrosa, C., \& Ferreira, S. T. (2003). Functional properties of purified vicilins from cowpea (Vigna unguiculata) and pea (Pisum sativum) and cowpea protein isolate. Journal of Agricultural and Food Chemistry, 51(19), 5792-5797.

Sathe, S. K., \& Salunkhe, D. K. (1981). Functional properties of the great northern bean (Phaseolus vulgaris L.) proteins: Emulsion, foaming, viscosity, and gelation properties. Journal of Food Science, 46(1), 71-81.

Sathe, S. K., \& Venkatachalam, M. (2007). Fractionation and biochemical characterization of moth bean (Vigna aconitifolia L.) proteins. LWT - Food Science and Technology, 40(4), 600-610.

Schmid, F. X. (1989). Spectra methods for characterizing protein conformation and conformational changes. In T. E. Creighton (Ed.), Protein structure: a practical approach, (pp. 251-285). New York: Springer Publication Co..

Shand, P. J., Ya, H., Pietrasik, Z., \& Wanasundara, P. K. J. P. D. (2007). Physicochemical and textural properties of heat-induced pea protein isolate gels. Food Chemistry, 102, 1119-1130.

Sharma, L., Singh, C., \& Sharma, H. (2016). Assessment of functionality of sesame meal and sesame protein isolate from Indian cultivar. Journal of Food Measurement and Characterization, 10(3), 520-526.

Tan, S. H., Mailer, R. J., Blanchard, C. L., \& Agboola, S. O. (2011). Extraction and characterization of protein fractions from Australian canola meals. Food Research International, 44(4), 1075-1082.

Tang, C.-H., \& Wang, X.-Y. (2010). Physicochemical and structural characterisation of globulin and albumin from common buckwheat (Fagopyrum esculentum Moench) seeds. Food Chemistry, 121(1), 119-126.

Uruakpa, F. O., \& Arntfield, S. D. (2005). Emulsifying characteristics of commercial canola protein-hydrocolloid systems. Food Research International, 38(6), 659-672.

Yin, S.-W., Chen, J.-C., Sun, S.-D., Tang, C.-H., Yang, X.-Q., Wen, Q.-B., \& Qi, J.-R. (2011). Physicochemical and structural characterisation of protein isolate, 
globulin and albumin from soapnut seeds (Sapindus mukorossi Gaertn.). Food Chemistry, 128(2), 420-426.

Yin, S. W., Tang, C. H., Wen, Q. B., \& Yang, X. Q. (2010). Functional and conformational properties of phaseolin (Phaseolus vulgris L.) and kidney bean protein isolate: A comparative study. Journal of the Science of Food and Agriculture, 90(4), 599-607.

Zakidou, P., \& Paraskevopoulou, A. (2021). Aqueous sesame seed extracts: Study of their foaming potential for the preparation of cappuccino-type coffee beverages. LWT - Food Science and Technology, 135, 110258. https://doi.org/ 10.1016/j.lwt.2020.110258

\section{Publisher's Note}

Springer Nature remains neutral with regard to jurisdictional claims in published maps and institutional affiliations.

Ready to submit your research? Choose BMC and benefit from:

- fast, convenient online submission

- thorough peer review by experienced researchers in your field

- rapid publication on acceptance

- support for research data, including large and complex data types

- gold Open Access which fosters wider collaboration and increased citations

- maximum visibility for your research: over $100 \mathrm{M}$ website views per year

At BMC, research is always in progress.

Learn more biomedcentral.com/submissions 